\title{
Research on Teaching Reforms of University English under the New Media Background
}

\author{
Li Yifei \\ Bohai University, Jinzhou, Liaoning, China, 121013 \\ liyifei163.com
}

Keywords: teaching reforms; university English; new media

\begin{abstract}
The arrival of the new media era provides a good opportunity for university English teaching reforms. This paper analyses the defects existing in traditional English teaching model and then points out the superiority of the English teaching model used new media, finally gives the reforms of university English teaching model under the background of new media in order to provide some references for the related researchers.
\end{abstract}

\section{Problems of Traditional English Teaching Model}

In the current college English teaching, classroom teaching is a major teaching model, and it will remain for a long period of time as the main teaching form. Although with since the reform and opening up to the outside world of English teaching evolution, at present the contents and methods of the English classroom teaching have great development, however, foreign language teaching and other disciplines, it is not to impart professional knowledge as the main purpose, but to cultivate the ability of students to apply knowledge. The traditional classroom teaching still has its inherent shortcomings.

\section{Unidirectional Channel of Information}

The traditional English teaching model is a kind of perfusion or lecture style teaching model in essence. In this mode of teaching, teachers more is used "indoctrination" method will be related to the language knowledge to students, the entire teaching activity, the flow of information basically is single and the one-way, that is, mainly by the teacher in the classroom from the beginning to the end of the lecture, from the text back background knowledge introduction to the related knowledge of the language points of focus analysis explains, from the whole text structure analysis to sentence drills and exercises in class until the final layout of the homework. And by the students in the class of things is to accept, always in a passive position, students do not have more is given opportunity to use language of thinking and communication, can only passively accept the teachers have taught the knowledge. The traditional classroom teaching has limited the full communication and information exchange between the teachers and students because of the limitation of time and the number of students. The teacher can only give the students the knowledge which is in line with the needs of the major of the students.

\section{Insufficient Interaction of Teacher-student}

Education should be composed ofby teachers' teaching and students' learning. However, the traditional teaching mode of English classroom is only teachers' teaching. The teacher fully accounts for the dominant position and students' participation of a few. Frequently consists of the following steps composition, teachers lead students to review the last lesson learned knowledge, teachers for students to explain the new knowledge, the teacher should lead the students to complete some after-school exercise, the teacher announced the answer exercises, students were recorded, teachers for the students' homework, day after day, year after year, all is so, this to teachers as the main body of the teaching mode not only let students become very passive and dependent, lets the student formed the habit of not thinking, mindless habits, while greatly reducing the participation of students of and enthusiasm for English learning. 


\section{Rigid Time of Education}

The traditional English classroom teaching model has not fully considered the differences between students. In the traditional teaching mode, the only way that students can use the teacher's teaching content is to keep the same with the teacher's teaching schedule. Therefore, students must step by step; no more choose learning content, learning methods and learning progress possible. In the form of classroom teaching, the students can learn and receive the freedom of knowledge and time arrangement. Different students have different understanding of the same knowledge content, but the content of the classroom teaching in the students after school retention time is very short. Because students also need to learn other courses, students in the latter part of self-digestion and absorption of teaching content, cannot reproduce the classroom teaching situation, cannot effective secondary learning to teach content. Therefore, we cannot really grasp the learning content. The student's individual differences not able to get full attention and effective solution of traditional classroom teaching, similarly limits upper subjective initiative and creativity of students' learning, and directly in the learning result of discount.

\section{Superiority of the English Teaching Model Used New Media}

\section{Expand Information Channels}

Compared with the traditional teaching model, the new media teaching not only the strengthen the content of interest, but also provide the information from various channels, such as electronic slides, film and television animation, network teaching software electronic teaching aids and network equipment can range to stimulate people's senses and improve the teaching information transmission efficiency, abstract language learning can become interesting audiovisual dynamic content, stimulate the students' curiosity and thirst for knowledge, help students understand and memory. Students can according to their own interest hobby, in view of the cultural background knowledge, anecdotes, to cultivate the students directly with foreign language thinking, training in listening, said, reading and writing ability, and improve the enthusiasm of learning has a positive meaning, is more helpful for students to adapt to the modern information age. In addition, the network conditions of various resources will be permanently preserved. Repeat the same content, the text of the reading, grammar, focus of the practice and other information can be numerous times according to the need to demonstrate. This function can improve the teaching effect and the independent learning ability.

\section{Strength Teacher-student Interaction}

New media technology has great advantages in image, sound and other aspects. It also provides a flexible interactive platform for participants. New media resources of teaching should be designed around the students how to learn "to set the context, let the students make use of the existing knowledge, seriously consider existing problems, to find out the relationship between each other, and try to solve it. In the process of cognition, let the students realize self enhancement. Also, the use of new media technology of active and interactive function, increase between teachers and students, the deep interaction between students, to enable students to actively participate in teaching activities, let students master the language situation in language practice. In today's society has entered the information age, the aim of English teaching is mainly in order to improve the students' communicative competence, so that people barrier free communication, thus more quickly and easily understanding the world around us, grasp the pulse of the times. Network for us provides rich resources, in English teaching should guide the students to be more in-depth development, and guide students to understand the rich culture of the network, constantly improve the students' comprehensive quality in culture. Teachers can obtain the material from the network to enrich the classroom teaching content. At the same time, the students are interested in the English network information layout, so that students through a large number of reading, increase the vocabulary, improve reading ability, make learning effect significantly enhanced. In short, the new media technology into the English language teaching has injected vigor and vitality. The network makes the students have a more comprehensive understanding of knowledge. 


\section{Broaden Education Time}

Teaching process is a two-way activity of teaching and learning. English is not only a language, but also a kind of skill. As a skill, language cannot be learned simply by a large amount of input, which requires constant communication. Under the new media environment, English teaching can break through the campus walls, break geographical boundaries, take teachers face-to-face instruction with students in the network, combining the teaching mode of autonomous learning, can enable more students to enjoy a higher level of teaching. New Media College English teaching characteristics make it able to do the classroom teacher-student communication. The teacher is to explain to the students in real time, face to face to the students, give students a demonstration and correct the students' mistakes. To provide students with a can be free to choose the learning space, students can according to their own circumstances to select the path and starting point, determine learning content and the number, select the suitable for their own learning difficulty, autonomous learning can take into account the learner's individual differences, highlight the individuality of teaching, greatly improves the student participation, to cultivate the students' self-learning ability, fully embody the teacher as the leading and students as the main body of the new teaching mode. New media teaching creates a multi-dimensional language environment, which can greatly improve the students' interest and enthusiasm in teaching activities.

\section{Reform Models of the Quality of Middle School English Teachers}

\section{Scene Creation Model}

The real purpose of teaching is not only to let the students get some knowledge taught by teachers, but also is to let the students can apply what they have learned to solve various problems in the real world. Therefore, the school to provide students with the learning situation cannot just abstract, boring, a single classroom, but should be vivid, specific. Only in the real world situation, learners can better devote time and energy, so that learning becomes more vivid and real. Teachers teach students to cultivate new era, the need to build the builders, then establish an advanced education concept is particularly important. Teachers must abandon the traditional teaching concept, continue to learn advanced teaching theory, the integration of information technology and teaching better, by providing real situation teaching, enhance teaching effect, cultivate the abilities of students, make the comprehensive development. There is no doubt that modern information technology give us achieve this purpose provides the possibility, film, animation, image integration, showing the a virtual environment, also is the voice, text images of the simulation to show, causing the students' great interest in learning, the learning process fun, improve the learning efficiency.

\section{Autonomic Learning Model}

School should not only pay attention to the cultivation of students' language competence and communicative competence, but also should pay attention to the cultivation of students' autonomous learning ability. The goal setting of English education should also be considered in two aspects, on the one hand, it should meet the needs of the skills learning; on the other hand, it should meet the needs of the era of continuous innovation. The teacher is not only the teaching of knowledge, but also the guide of students' learning how to learn. The students construct the new knowledge system through autonomous learning mode, so as to achieve the goal. English teaching should emphasize the students' subject consciousness, advocate for students to choose the needed materials and in accordance with the methods suitable for their own learning, in the process, students take the initiative to study the ability to get increased rapidly. New media technology should be transformed from the teaching tool to the learning tool, for students to explore in the knowledge of the ocean to provide a broad space. This novel research learning model requires students to experience, personally operate, to obtain knowledge, it has great significance for the students' learning style. With the rapid development of information society, the teaching technology is increasing with the increasing of the practical teaching needs. Teachers only have modern education concept is not enough, but also continue to learn advanced teaching technology, only continue to improve their business level and professional quality, the pace to keep up with the times. As a teacher should be the cultivation of students' lifelong learning ability as the main purpose of education and teaching, 
in order to achieve this goal, to continue to "recharge", consciously take the initiative to learn new knowledge and new technology. After the integration of information technology and curriculum, teachers can study the task assigned to students through the network, so that students can collect materials, and then analyze the data, and finally complete the project. In this process, students learn the language knowledge, but more important is to develop the students' ability to analyze and solve problems. Teachers should give the necessary guidance to provide related websites and other related help.

\section{Conclusion}

With the social development of new information technology, the pace of the reform of university English teaching in our country also accelerates its improvement. It is undeniable denied that it also has drawbacks of the traditional English teaching model is not is no desirable, together with teachers and students for a long time has been adapted and accustomed to the traditional teaching mode, so this requires us to make full use of the advantages of multimedia technology continue to innovate the mode of university English teaching, improve teaching efficiency, enrich the teaching structure, stimulate students interest in learning. At the same time, we should also combine the traditional mode of educationwith the new media technology in order to achieve the best teaching effects.

\section{References}

[1] Cao Liping, Towards the use of New Media in College English Listening Teaching-a Case Study of Autonomous Learning Web Platforms inShanghai Normal University, D. Shanghai Normal University. 2014

[2] Tang Yanhua. The Socially Networked Classroom: Teaching in the New Media Age. J. Overseas English. 2011(4): 132-133.

[3] Zhang Yan. The innovation of the Theory of the New Media Era of English Education. J. Journal of Jiamusi Vocational Institute. 2014(8):15-17 